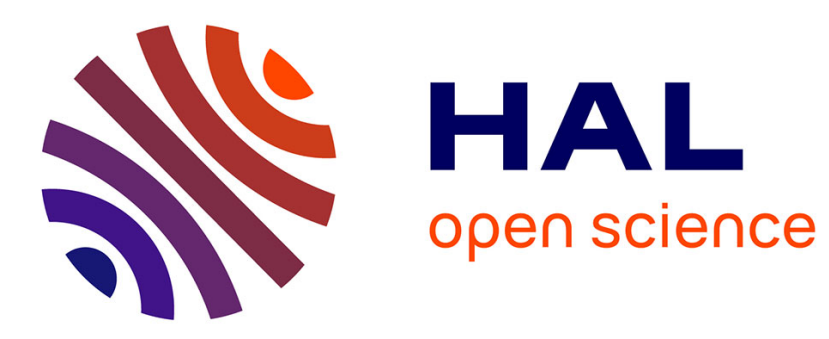

\title{
Effect of staged air on heat transfer in circulating fluidized beds
}

\author{
M. Koksal, M.R. Golriz, F. Hamdullahpur
}

\section{To cite this version:}

M. Koksal, M.R. Golriz, F. Hamdullahpur. Effect of staged air on heat transfer in circulating fluidized beds. Applied Thermal Engineering, 2008, 28 (8-9), pp.1008. 10.1016/j.applthermaleng.2007.06.028 . hal-00498958

\section{HAL Id: hal-00498958 https://hal.science/hal-00498958}

Submitted on 9 Jul 2010

HAL is a multi-disciplinary open access archive for the deposit and dissemination of scientific research documents, whether they are published or not. The documents may come from teaching and research institutions in France or abroad, or from public or private research centers.
L'archive ouverte pluridisciplinaire HAL, est destinée au dépôt et à la diffusion de documents scientifiques de niveau recherche, publiés ou non, émanant des établissements d'enseignement et de recherche français ou étrangers, des laboratoires publics ou privés. 


\section{Accepted Manuscript}

Effect of staged air on heat transfer in circulating fluidized beds

\section{APPLIED}

THERMAL

ENGINEERING

M. Koksal, M.R. Golriz, F. Hamdullahpur

PII:

S1359-4311(07)00227-X

DOI:

10.1016/j.applthermaleng.2007.06.028

Reference:

ATE 2216

To appear in:

Applied Thermal Engineering

Received Date: $\quad 25$ December 2006

Accepted Date: $\quad 25$ June 2007

Please cite this article as: M. Koksal, M.R. Golriz,F. Hamdullahpur,Effect of staged air on heat transfer in circulating fluidized beds, Applied Thermal Engineering (2007), doi: 10.1016/j.applthermaleng.2007.06.028

This is a PDF file of an unedited manuscript that has been accepted for publication. As a service to our customers we are providing this early version of the manuscript. The manuscript will undergo copyediting, typesetting, and review of the resulting proof before it is published in its final form. Please note that during the production process errors may be discovered which could affect the content, and all legal disclaimers that apply to the journal pertain. 


\title{
EFFECT OF STAGED AIR ON HEAT TRANSFER IN CIRCULATING FLUIDIZED BEDS
}

\author{
M. Koksal ${ }^{1}$, M. R. Golriz ${ }^{2 \& 3}$, F. Hamdullahpur ${ }^{3}$ \\ ${ }^{1}$ Department of Mechanical Engineering, Hacettepe University, Beytepe, 06800, \\ Ankara, Turkey \\ ${ }^{2}$ Department of Applied Physics and Electronics, Umea University, SE- 901 87, Umea, \\ Sweden \\ ${ }^{3}$ Mechanical and Aerospace Eng. Dept., Carleton University Ottawa, ON, K1S 5B6, \\ Canada
}




\section{Abstract}

The purpose of this work is to develop a model for bed-to-surface heat transfer in Circulating Fluidized Bed (CFB) risers with secondary air (SA) injection. The heat transfer coefficient is correlated to cross-sectionally averaged solids hold-up. The average solids hold-up was correlated with the operating and design parameters of CFB risers with SA injection. The data used in developing the correlations cover a range of 2.0 to $8.6 \mathrm{~m} / \mathrm{s}$ for superficial gas velocity, 5 to $100 \mathrm{~kg} / \mathrm{m}^{2} \mathrm{~s}$ for solids circulation rate, 0 0.6 for secondary to primary air ratio, and 60 to $300 \mu \mathrm{m}$ for particle diameter (Groups A and B). The predictions obtained with the correlations show good agreement with the experimental data. Furthermore, an experimental correlation, developed in our previous work for prediction of wall-to-bed heat transfer coefficient was used in a parametric study to investigate the effects of design and operating parameters on heat transfer.

Keywords: Circulating fluidised bed; Secondary air injection; Solids hold-up; Heat transfer.

\section{List of Symbols}

\footnotetext{
a constant in Eq. (8), -

$b \quad$ constant in Eq. (8), -

Ar Archimedes number, $=d_{p}^{3} \beta(\beta-\beta) g / \not ̈$, -

$e_{\text {sus }} \quad$ emissivity of suspension surface, -

$e_{w} \quad$ emissivity of wall/heat transfer surface, -
} 
$D_{r} \quad$ riser diameter, $\mathrm{m}$

$d_{p} \quad$ particle mean diameter, $\mathrm{m}$

$h_{\text {tot }} \quad$ overall heat transfer coefficient, $\mathrm{W} / \mathrm{m}^{2} \mathrm{~K}$

$h_{\text {rad }}$ radiative heat transfer coefficient, $\mathrm{W} / \mathrm{m}^{2} \mathrm{~K}$

$h_{c} \quad$ total convective heat transfer coefficient, $\mathrm{W} / \mathrm{m}^{2} \mathrm{~K}$

$h_{c, g} \quad$ gas convection heat transfer coefficient, $\mathrm{W} / \mathrm{m}^{2} \mathrm{~K}$

$h_{c, p} \quad$ particle convective/conductive heat transfer coefficient, $\mathrm{W} / \mathrm{m}^{2} \mathrm{~K}$

$H_{S A} \quad$ height of SA injection port, $\mathrm{m}$

$H_{r} \quad$ height of riser, $\mathrm{m}$

$g$ gravitational acceleration, $\mathrm{m}^{2} / \mathrm{s}$

$\mathrm{G}_{\mathrm{s}} \quad$ solids circulation rate, $\mathrm{kg} / \mathrm{m}^{2} \mathrm{~s}$

$n \quad$ constant in Eq. (8), -

$T_{b} \quad$ bulk temperature, $\mathrm{K}$

$T_{w} \quad$ Wall temperature, $\mathrm{K}$

$U_{0} \quad$ superficial gas velocity, $\mathrm{m} / \mathrm{s}$

$U_{S A} \quad$ SA gas velocity, $\mathrm{m} / \mathrm{s}$

Eus cross-sectional solids hold-up, -

$\mu \quad$ gas viscosity, $\mathrm{kg} / \mathrm{m} \mathrm{s}$

B gas density, $\mathrm{kg} / \mathrm{m}^{3}$

B particle density, $\mathrm{kg} / \mathrm{m}^{3}$

Bus suspension density, $\mathrm{kg} / \mathrm{m}^{3}$

$\sigma \quad$ Stefan-Boltzmann's constant, $5.67 \times 10^{-8} \mathrm{~W} / \mathrm{m}^{2} \mathrm{~K}^{2}$ 


\section{Introduction}

Circulating fluidized beds (CFBs) have been successfully used in fossil fuel combustion, coal and biomass gasification, and fluid catalytic cracking. In combustion and gasification, CFB technology offers significant advantages such as fuel flexibility, in-bed sulfur capture, and relatively low $\mathrm{NO}_{\mathrm{x}}$ emissions with high efficiencies. In many fluidized bed applications it is necessary to add or extract heat in order to maintain the operating temperature at a desired value [1]. The design and scale-up of heat transfer surfaces require the knowledge of the bed hydrodynamics and heat transfer coefficient at the wall surfaces in contact with the fluidized mass. Suspension density - mass of the solids per unit volume of the flow - is generally recognized as a dominant parameter influencing the CFB heat transfer and the cross-sectional average suspension density has been found to correlate well with the bed-surface-heat transfer coefficient [1-6].

In a CFB combustor, air staging or the so-called secondary air (SA) injection, in addition to a number of advantages, is mainly employed to control the nitrogen oxide $\left(\mathrm{NO}_{\mathrm{x}}\right)$ formation especially in combustion of highly volatile fuels. The total combustion air is split into primary and secondary streams, where the secondary air is injected to the riser at a certain height above the distributor plate. It is known that the introduction of SA jets has a profound impact on the axial variation of the solids hold-up [7-12]. For instance, SA injection increases the suspension density below the SA injection port due to decreased flow rate and cut off effect of the SA jets compared to non-SA operation at the same superficial gas velocity and solids circulation rate. Furthermore, the effect of 
SA has been found to be dependent on the type of the injector, height of the injection port from the distributor plate, amount of SA injected, particle properties and riser geometry [9].

Figure 1 shows the typical flow patterns induced by a radial and a tangential (swirl) injector. In case of the tangential injector, the flow enters the riser in a helical path whereas two opposing jets impinge on each other in radial injection. Generally, the tangential injector results in higher solids hold up compared with radial injector below and above the SA injector ports increasing the mean solids hold-up which in turn increases the bed-to-surface heat transfer coefficient significantly [6,9]. This was attributed to the increased residence time of solids in the bed due to their helical motion. The effect of SA air also increases with increasing amount of SA.

Despite the presence of these trends, there is still not a practical model that can be used to predict the bed-to-wall heat transfer coefficient in CFBs under SA injection conditions covering a wide range of operating conditions. Recently, Koksal et al. [6] showed that the bed-to-surface heat transfer coefficient in a CFB riser could be correlated with cross-sectionally averaged suspension density even when it is operated with SA injection. The problem is then to relate the average suspension density (or solids hold-up) to the operating and design conditions, which are summarized in Table 1.

Cho et al. [7] developed a correlation for the variation of solids hold-up in a CFB riser with SA injection based on the freeboard entrainment model of Kunii and Levenspiel [13]. The decay constants for the model were determined by the experimental data of the authors and the model did not consider the effect of the type of the injector. Kang et 
al. (2000) proposed correlations for the mean solids hold-up below and above the SA injection ports for both tangential and radial SA injection based on the experiments carried out in a $0.102 \mathrm{~m}$ ID riser with FCC particles. Their correlations used the superficial gas velocity, solids circulation rate and secondary-to-primary air flow ratio as the model parameters. However, their correlations were also limited by the operating conditions used in their experimental study.

In this study, we propose two general correlations for the mean solids volume fraction below and above the SA injection ports for both tangential and radial SA injectors. The correlations are based on a pool of data, which cover a wide range of operating and design conditions pertinent to CFB risers with air staging. Coupling these correlations with Koksal et al.'s [6] empirical correlation for bed-to-surface heat transfer enable the prediction of heat transfer coefficient in CFB risers with SA injection.

\section{Experimental apparatus and material}

Figure 2 shows the schematics of the experimental CFB assembly. High-velocity fluidization up to $5.5 \mathrm{~m} / \mathrm{s}$ can be maintained in a $0.23-\mathrm{m} \mathrm{ID,} \mathrm{7.62-m} \mathrm{high} \mathrm{transparent}$ column. Fluidization air is supplied from a roots-type blower. A bypass valve is used to control the amount of air into the riser before entering the plenum. The solids are fed into the vertical column from a rectangular Plexiglas return box, which is used as a solids reservoir. The flow of solids into the riser is controlled by pressurized air injected into the opposite side of the box. The solids leaving the riser are collected by a cyclone and a bag filter. The collected solids are returned to the solids reservoir via a return leg. SA is injected into the riser via two identical lines located symmetrically with respect to 
the vertical axis of the riser as shown in Fig. 1. The modular SA injection unit is composed of a steel body and two injection nozzles. The detailed description of the unit was described elsewhere, see $[9,14]$.

The operating conditions for the tests covered a range of secondary-to-primary air ratio (SA/PA) from 0.0 to 0.6 , superficial gas velocity from 3 to $5 \mathrm{~m} / \mathrm{s}$, solids circulation rate from 5 to $33 \mathrm{~kg} / \mathrm{m}^{2} \mathrm{~s}$, height of SA injection from 0.52 to $1.82 \mathrm{~m}$ above the distributor plate, for radial and tangential injectors. Two different types of bed material, namely, silica sand of mean diameter $300 \mu \mathrm{m}$ and particle density of $2650 \mathrm{~kg} / \mathrm{m}^{3}$ and FCC particles with mean diameter of $60 \mu \mathrm{m}$ and particle density of $1600 \mathrm{~kg} / \mathrm{m}^{3}$, were used in the experiments.

\section{Development of the Solids Hold-Up Correlations}

In order to develop a general correlation for mean solids hold-up in CFB risers with SA injection, data from various investigators have been gathered along with the data produced in a pilot scale CFB riser as seen in Table 1.

Figures 3 and 4 show the effect of radial and tangential SA injection on the axial solids hold-up distribution in the riser at the given conditions for different SA/PA ratio, respectively. As seen from the figures, below the SA injection port, regardless of the type of the injector, SA injection causes an increase in the suspension density due to decreased gas flow rate in the primary region and cut-off effect of the SA jets. Above the SA injection port tangential SA injector results in a higher suspension density compared with non-SA operation. The radial SA injector, on the other hand, does not significantly alter the suspension density. The effect of SA on suspension density 
increases with increasing SA/PA. These results are typical of a CFB riser with air staging. It should also be noted that the suspension density increases with increasing solids circulation rate for both SA and non-SA operations at constant superficial gas velocity.

In the development of the correlations, the data sets tabulated in Table 1 were used. The experimental data corresponded to design and operating conditions ranging 5 to 100 $\mathrm{kg} / \mathrm{m}^{2} \mathrm{~s}$ for solids circulation rate, 2.0 to $8.6 \mathrm{~m} / \mathrm{s}$ for superficial gas velocity, 0.09 to 0.56 for $\mathrm{U}_{\mathrm{SA}} / \mathrm{U}_{0}, 60$ to $300 \mu \mathrm{m}$ for particle mean diameter, $1600 \mathrm{~kg} / \mathrm{m}^{3}$ to $2650 \mathrm{~kg} / \mathrm{m}^{3}$ for particle density, 0.09 to 0.48 for $\mathrm{H}_{\mathrm{SA}} / \mathrm{H}_{\mathrm{r}}$, and 0.10 to $0.23 \mathrm{~m}$ for riser diameter. A rigorous dimensionless analysis coupled with a comprehensive statistical analysis resulted in the following three non-dimensional parameters to be used in the empirical correlations for mean solids volume fraction with SA:

$$
\frac{d_{p}^{3} \rho_{g}\left(\rho_{p}-\rho_{g}\right) g}{\mu^{2}}, \frac{G_{s}}{\rho_{p} U_{0}\left(1-\frac{U_{S A}}{U_{0}}\right)} \text { and }\left(1-\frac{H_{S A}}{H_{r}}\right)
$$

These three parameters describe and correlate the effects of solids circulation rate, the amount of SA, and SA injection height, respectively. Furthermore, the properties of the bed material and fluidization gas are also taken into account. The solids volume fraction correlations were developed using these three dimensionless parameters with least square analysis for two zones above and below the secondary air injection ports (also called secondary and primary zones). The mean solids hold-up, $\varepsilon_{u s}$ for radial SA injection is determined as: 


$$
\begin{array}{ll}
\mathcal{E}_{\text {sus }}=3.30(A r)^{0.27}\left(1-\frac{H_{S A}}{H_{r}}\right)^{-3.24}\left(\frac{G_{s}}{\rho_{p}\left(U_{0}-U_{S A}\right)}\right)^{1.26} & \text { primary zone } \\
\varepsilon_{\text {sus }}=1.16(A r)^{0.06}\left(1-\frac{H_{S A}}{H_{r}}\right)^{-0.86}\left(\frac{G_{s}}{\rho_{p}\left(U_{0}-U_{S A}\right)}\right)^{0.97} & \text { secondary zone }
\end{array}
$$

which represent the statistically best fits to the available data in Table 1 . The maximum and mean deviations of the data from these equations are $60 \%$ and $28 \%$ for the primary zone and $57 \%$ and $27 \%$ for the secondary zone, respectively, as shown in Figure 5.

The following correlations were obtained for the mean solids volume fraction with the tangential SA:

$$
\begin{array}{ll}
\varepsilon_{\text {sus }}=63.20(A r)^{0.52}\left(1-\frac{H_{S A}}{H_{r}}\right)^{-3.11}\left(\frac{G_{s}}{\rho_{p}\left(U_{0}-U_{S A}\right)}\right)^{1.94} \quad \text { primary zone } \\
\varepsilon_{\text {sus }}=12.93(A r)^{0.35}\left(1-\frac{H_{S A}}{H_{r}}\right)^{-2.06}\left(\frac{G_{s}}{\rho_{p}\left(U_{0}-U_{S A}\right)}\right)^{1.64} \quad \text { secondary zone }
\end{array}
$$

which again represent the statistically best fits to the available data in Table 1 . The maximum and mean deviations of the data from these equations are $49 \%$ and $21 \%$ for the primary zone and $62 \%$ and $21 \%$ for the secondary zone, respectively, as shown in Figure 6. 
It should be noted that the suspension density, $\beta$, is related to the solids volume fraction as:

$\beta_{u s} \approx \beta \varepsilon_{u s}$

and $\xi_{u s}$ is determined from Equations (1) to (4).

\section{Heat Transfer}

In general, the heat transfer between the riser wall and the bed material in a fluidized bed occurs by particle convection/conduction, gas convection and by radiation in the case of high temperature $(>500)$. Thus:

$h_{t o t}=h_{c, p}+h_{c, g}+h_{r a d}$

where $h_{t o t}, h_{c, p}, h_{c, g}$, and $h_{r a d}$ are the overall effective heat transfer coefficient, particle convective/conductive heat transfer coefficient, gas convective heat transfer coefficient, and radiative heat transfer coefficient, respectively. It is usually assumed that the three heat transfer coefficients on the right-hand side above are independent. Golriz and Sunden (1994) correlated the overall bed-to-surface heat transfer coefficient as the sum of two uncoupled component in the form of

$$
h_{t o t}=h_{c}+h_{r a d}
$$


where $h_{c}$ is the total convective heat transfer coefficient. This approach is also followed here.

A number of researchers and operators of large CFB combustors $[2,3,15,16]$ and laboratory-scale CFB risers $[4,6]$ have found a clear relationship between overall heat transfer coefficient and suspension density, $\beta_{u s}$, correlating their heat transfer data by an equation of the general form:

$h_{\text {tot }}=a \rho_{\text {sus }}^{n}+b$

Values of $a, b$ and $n$ are constants, fitted for a certain ranges of conditions. Koksal et al.

[6] proposed the following correlation for the convective bed-to-surface heat transfer coefficient in a CFB with SA injection:

$h_{c}=17.2 \rho_{\text {sus }}^{0.58}$

where $h_{c}$ is the total convective heat transfer coefficient in $\mathrm{W} / \mathrm{m}^{2} \mathrm{~K}$ and $\rho_{u s}$ is suspension density in $\mathrm{kg} / \mathrm{m}^{3}$.

Radiation between the suspension and the riser wall can be estimated from the parallel surface expression, 


$$
h_{\text {rad }}=\frac{\sigma\left(T_{b}^{4}-T_{w}^{4}\right)}{\left(T_{b}-T_{w}\right)\left(\frac{1}{e_{\text {sus }}}+\frac{1}{e_{w}}-1\right)}
$$

where $T_{b}$ and $T_{w}$ are the bulk and wall/surface temperatures, while $e_{w}$ and $e_{s u s}$ are the wall and suspension emissivities. The latter is estimated from the Brewster [17] correlation. For most metallic surfaces operating at high temperatures, $e_{w}$ tends to be in the range of $0.7-1.0$. Thus, a simple engineering estimate of the radiative heat transfer coefficient can be obtained. More comprehensive models are available e.g. [18-20] that adopt more rigorous approaches. In this work the radiation is neglected because all the correlated data are from cold (room temperature) CFB risers.

While equations of this simple form may correlate data in a single unit held at relatively constant temperature, they clearly exclude key variables aside from suspension density that affect heat transfer, see Golriz and Grace [21], and Koksal et al. [6] among others. The dependency of heat transfer on the operating and design conditions in a CFB riser with SA can be somewhat taken into account by combining Equations (1) to (5) with Equations $(7,8,10)$. These sets of equations specifically developed for CFBs with air staging can then be used to predict the bed-to-surface heat transfer coefficient and study the influence of various operating and design parameters on the total heat transfer coefficient. The model equations were applied to the operating conditions of the pilot scale CFB. The parameters used in the implementation of the model equations are given in Table 2. 
Figures 7 to 9 show the variation of the overall heat transfer coefficient with secondaryto-primary air ratio, solids circulation rate, and secondary air injection port height-tobed height ratio, respectively for both radial and tangential injectors in primary and secondary air zones. As indicated before, the primary and secondary zones refer to regions below and above SA injection port in the riser, respectively.

The figures indicate that the heat transfer coefficient in the primary zone is always higher than that in the secondary zone due to higher suspension density. Another common feature in these figures is the higher heat transfer coefficients obtained in case of tangential SA injection compared to radial injection. This is more pronounced at higher $\mathrm{SA} / \mathrm{PA}$ and $\mathrm{G}_{\mathrm{s}}$ values.

The heat transfer coefficient shows increasing trends with $\mathrm{SA} / \mathrm{PA}, \mathrm{G}_{\mathrm{s}}$ and $\mathrm{H}_{\mathrm{SA}} / \mathrm{H}_{\mathrm{r}}$, which can be explained by the fact that increase in suspension density would increase the wall coverage and annulus wall layer, thereby increasing the conductive component of the overall heat transfer coefficient. This is consistent with the experimental results reported by $[6,22,23]$. Furthermore, as can be seen from Figure 9, the SA injector height-to-bed height ratio does not play a major role for the heat transfer coefficient in the secondary zone as well as it does for the primary zone. This is an important result since most of the heat transfer surfaces in CFBs are placed in the secondary zone.

\section{Conclusions}


An empirical model for bed-to-surface heat transfer in circulating fluidized beds (CFB) with secondary air (SA) injection is presented. The model incorporates a correlation that relates the heat transfer coefficient to cross-sectionally averaged solids hold-up based on Koksal et al.'s (2005) work and a new set of empirical correlations for the average solids hold up in CFB risers operated with SA injection. This new set of correlations were developed using least square analysis for a wide range of data available in the literature as well as the data obtained in this study for both radial and tangential SA injector types. Given the complexity of the problem and the vast number of parameters affecting the solids hold-up, the maximum and mean deviations from the experimental values were found to be $62 \%$ and $24 \%$, respectively.

A parametric study of bed-to-wall heat transfer coefficient with SA injection shows that heat transfer coefficient increases with solids circulation rate, secondary to primary air ratio, and SA injection height for both radial and tangential injectors. Furthermore, the results indicate that higher heat transfer coefficients can be obtained with tangential SA injector compared to radial injector in both primary and secondary zones in the bed. These trends agree well with available experimental data.

\section{Acknowledgements}

The authors are grateful to the Natural Science and Engineering Research Council of Canada for their support. 


\section{References}

[1] Chen, C.J., Grace, J.R., and Golriz, M.R., 2005, Heat Transfer in Fluidized Beds, Design Methods, Powder Technology, 150, pp. 123-132.

[2] Golriz, M.R. and Sunden, B., 1994, An Experimental Investigation of Thermal Characteristics in a 12 MWth CFB Boiler, Experimental Heat Transfer J., 7, 217233.

[3] Andersson, B-Å., 1996, Effect of Bed Particle Size on Heat Transfer in Circulating Fluidized Bed Boilers, Powder Technology, 87, 239-248.

[4] Basu, P. and Nag, P. K., 1996, Heat Transfer to Walls of a Circulating FluidizedBed Furnace, in Chemical Engineering Science 51, pp. 1-26.

[5] Dutta, A. and Basu, P., 2003, An Improved Cluster-Renewal Model for Estimation of Heat Transfer Coefficients on the water-Walls of Commercial Circulating Fluidized Bed Boilers, Int. Fluid Bed Combustion Conf., Jacksonville, Florida, FBC 2003-042.

[6] Koksal M., Golriz M.R. and Hamdullahpur, F., 2005, Thermal Aspects of a Circulating Fluidized Bed with Air Staging, Int. J. of Energy Research, Vol. 29, 10, 913-921.

[7] Cho, J.Y., Namkung, W., Kim, S.D., and Park, S., 1994. Effect of Secondary Air 
Injection on Axial Solid Holdup Distribution in a Circulating Fluidized Bed, J. Chem. Eng. Japan, 27(2), 158-164.

[8] Marzocchella, A., and Arena, U., 1996, Hydrodynamics of a Circulating Fluidized Bed Operated with Different Secondary Air Injection Devices, Powder Technology, 87, 185-191.

[9] Ersoy, L.E., Golriz M.R., Koksal M. and Hamdullahpur, F., 2004, Circulating Fluidized Bed Hydrodynamics with Air Staging: An Experimental Study, Powder Technology, 145, 25-33.

[10] Kang, Y., Song, P.S., Yun, S.J., Jeong, Y.Y., and Kim, S.D., 2000, Effects of Secondary Air Injection on Gas-Solid Flow Behavior in Circulating Fluidized Beds, Chem. Eng. Comm., 177, 31-47.

[11] Sun, G., Liu, H., and Shi, M., 2002, Hydrodynamic Behavior of a Cold FCC Riser with Secondary Air Injection”, in Circulating Fluidized Beds Technology VII, J. R. Grace, J. Zhu, H. de Lasa, Eds., Canadian Society for Chemical Engineering, Ottawa, Canada, 373-379.

[12] Brereton, C., Grace, J.R., 1993, End Effects in Circulating Fluidized Bed Hydrodynamics, in Preprints of CFB IV, ed., Avidan, A.A., 169-174.

[13] Kunii, D. and Levenspiel, O., 1991. Fluidization Engineering, 2nd edition, 
Butterworth-Heinemann, Boston, 1991.

[14] Koksal, M., and Hamdullahpur, F., 2004, Gas Mixing in Circulating Fluidized Beds with Secondary Air Injection, Chem. Eng. Res. Design, 82, 1-14.

[15] Kobro H. and C. M. H. Brereton, 1986, Control and Fuel Flexibility of Circulating Fluidized Beds. In: P. Basu Ed. Circulating Fluidized Bed Technology 1, Toronto: Pergamon, 263-272.

[16] Weimer, A., D. Bixler, R. D. Pettit and S. I. Wang, 1991, Operation of a 49 MW Circulating Fluidized Bed Combustor, In: P. Basu, M. Hasatani and M. Horio (eds.) Circulating Fluidized Bed Technology II. Oxford: Pergamon Press, 341346.

[17] Brewster, M.Q., Effective Absorptivity and emissivity of Particulate Media with Application to Fluidized Bed, Trans. ASME 108 (1986) 710- 713.

[18] Xie, D., Bowen, B.D., Grace, J.R. and Lim, C.J., 2003, Two-dimensional model of heat transfer in circulating fluidized beds: Part I. Model development and validation. Int. J. Heat Mass Transfer, 46, 2179-219.

[19] Xie, D., Bowen, B.D., Grace, J.R. and Lim, C.J., 2003, Two-dimensional model of heat transfer in circulating fluidized beds: Part II Heat transfer in a high density CFB and sensitivity analysis, Int. J Heat Mass Transfer, 46, 2193-2205. 
[20] Eriksson, M. and Golriz, M.R., Radiative Heat Transfer in Circulating Fluidized Beds, Int. J. of Thermal Sciences, 44, pp. 399-409, 2005.

[21] Golriz, M.R. and Grace, J.R., 2002, Predicting Heat Transfer in Large-Scale CFB Boilers, in Circulating Fluidized Beds Technology VII, J.R. Grace, J. Zhu, H. de Lasa, Eds., Canadian Society for Chemical Engineering, Ottawa, Canada, 121128.

[22] Baskakov, A.P., Maskaev, V.K., Usoltsev, A.G., Ivanov, I.V., and Zubkov, V.A.,1993, Influence of Secondary Air on Convective Heat Transfer Between Walls of Riser and Circulating Fluidized Bed (CFB), in Preprints of CFB IV, ed., Avidan, A.A., 324-327.

[23] Cho, J.Y., Namkung, W., Kim, S.D., Park, S., and Kim, P.T., 1996, Effect of Secondary Air Injection On Bed-To-Wall Heat Transfer in a Circulating Fluidized Bed, J. of Chem. Eng. Japan, 29 (1), 44-50. 


\section{Figure Captions}

Figure 1. Tangential (a) and radial (b) secondary air injector.

Figure 2. Schematics of the circulating fluidized bed. P1-P8 indicate pressure taps positions.

Figure 3. Axial solids hold-up profiles for various radial- (a) and Tangential (b) injection of secondary air rates. Dashed line indicates the secondary air injection height. Conditions: (a) Silica sand particles, $\mathrm{G}_{\mathrm{s}}=8 \mathrm{~kg} / \mathrm{m}^{2} \mathrm{~s}, \mathrm{U}_{0}=5.0$ $\mathrm{m} / \mathrm{s}$; (b) FCC particles, $\mathrm{G}_{\mathrm{s}}=18 \mathrm{~kg} / \mathrm{m}^{2} \mathrm{~s}, \mathrm{U}_{0}=3.0 \mathrm{~m} / \mathrm{s}$.

Figure 4. Experimental vs predicted mean solids volume fraction for radial SA injection, a) primary zone, b) secondary zone. $\Delta$ Sun et al. [11]; $\times$ Brereton

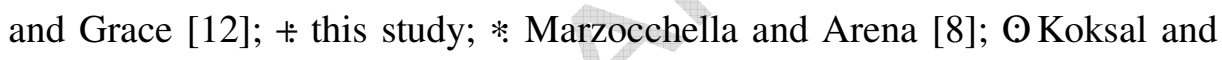
Hamdullahpur [14]; : Cho et al. [7]; $\square$ : Kang et al. [10].

Figure 5. Experimental vs predicted mean solids volume fraction for tangential SA injection, a) primary zone, b) secondary zone. $\times$ Brereton and Grace [12]; +. this study; * Marzocchella and Arena [8]; @Koksal and Hamdullahpur [14]; : Cho et al. [7]; $\square$ : Kang et al. [10].

Figure 6. Variation of heat transfer coefficient with secondary-to-primary air.

Figure 7. Variation of heat transfer coefficient with solids circulation rate.

Figure 8. Variation of heat transfer coefficient with secondary air injection port height-to-riser height ratio 


\section{ACCEPTED MANUSCRIPT}

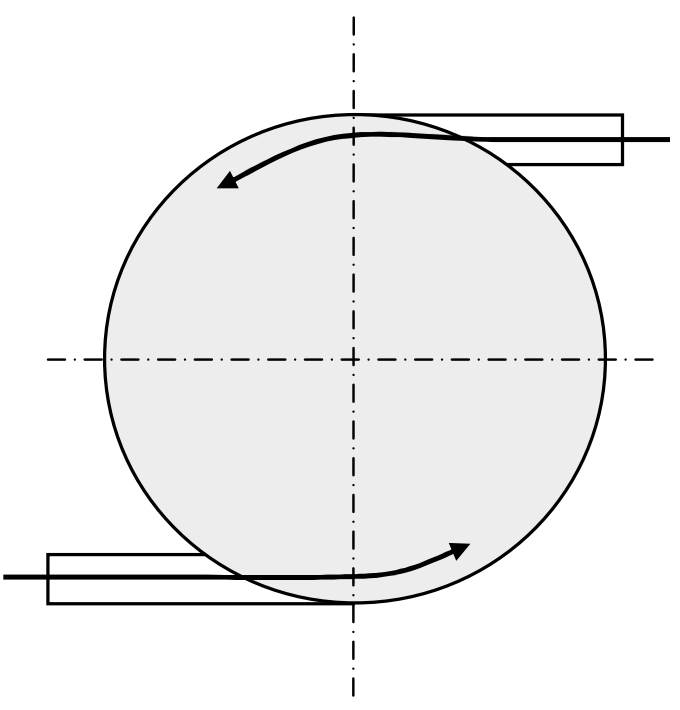

(a)

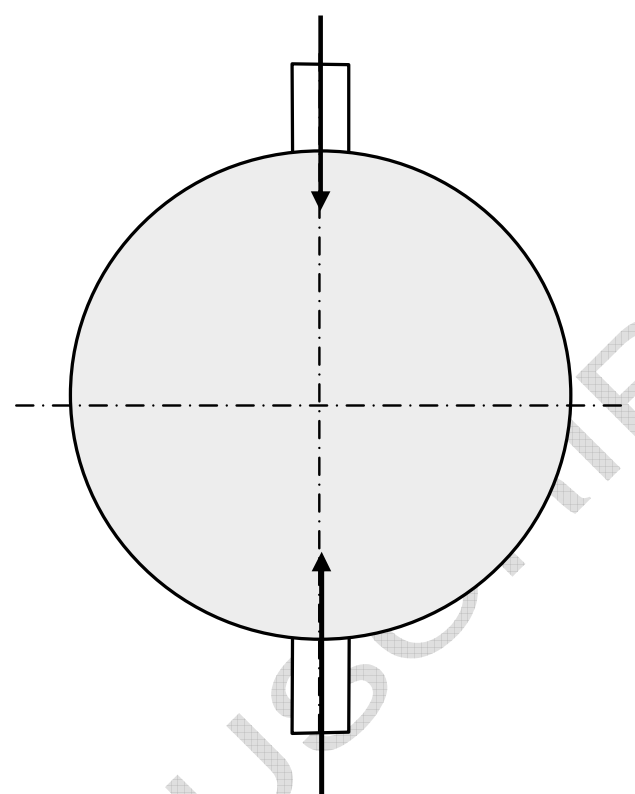

(b)

Figure 1.

Koksal et al. 


\section{ACCEPTED MANUSCRIPT}

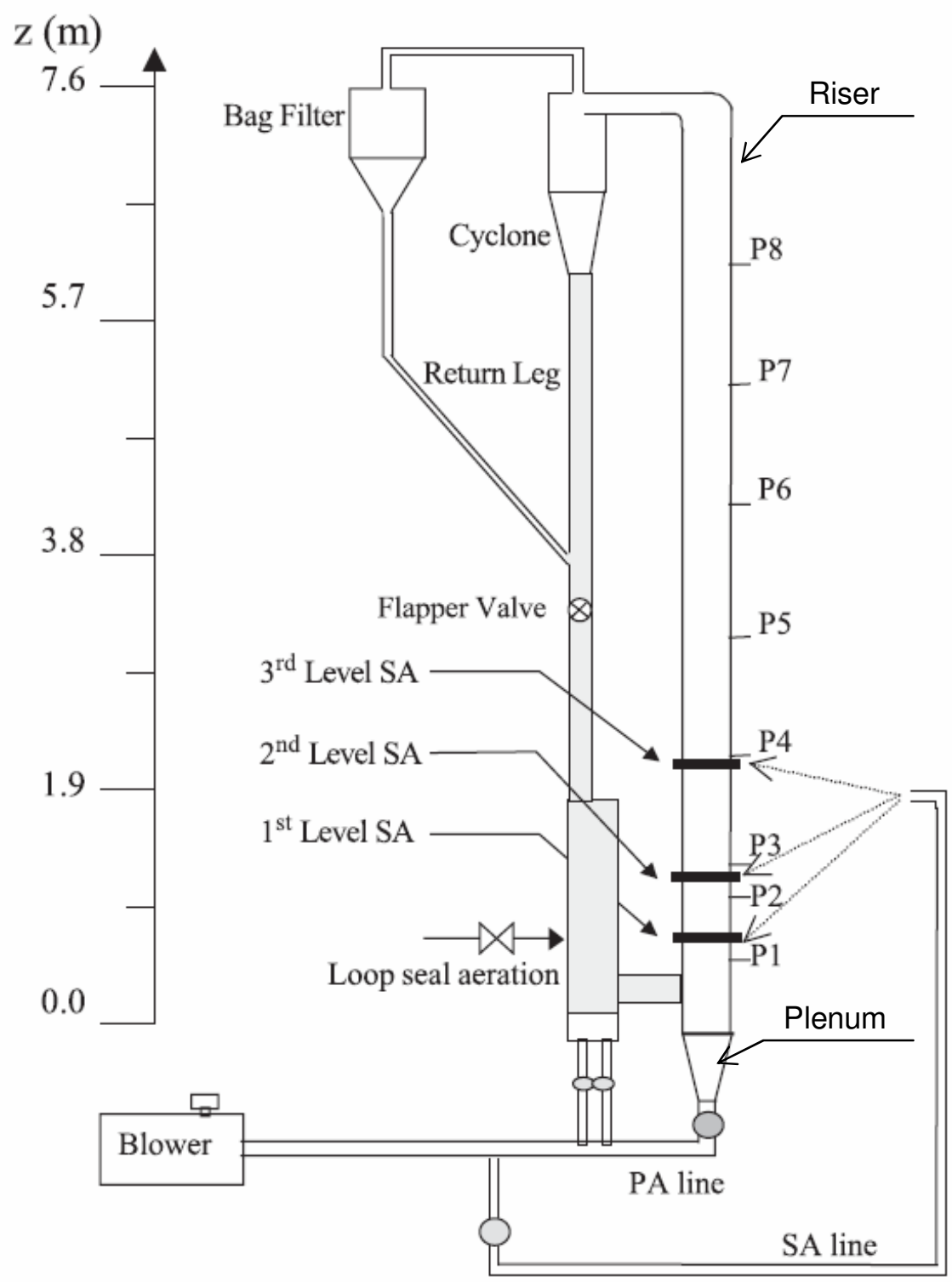

Figure 2.

Koksal et al. 


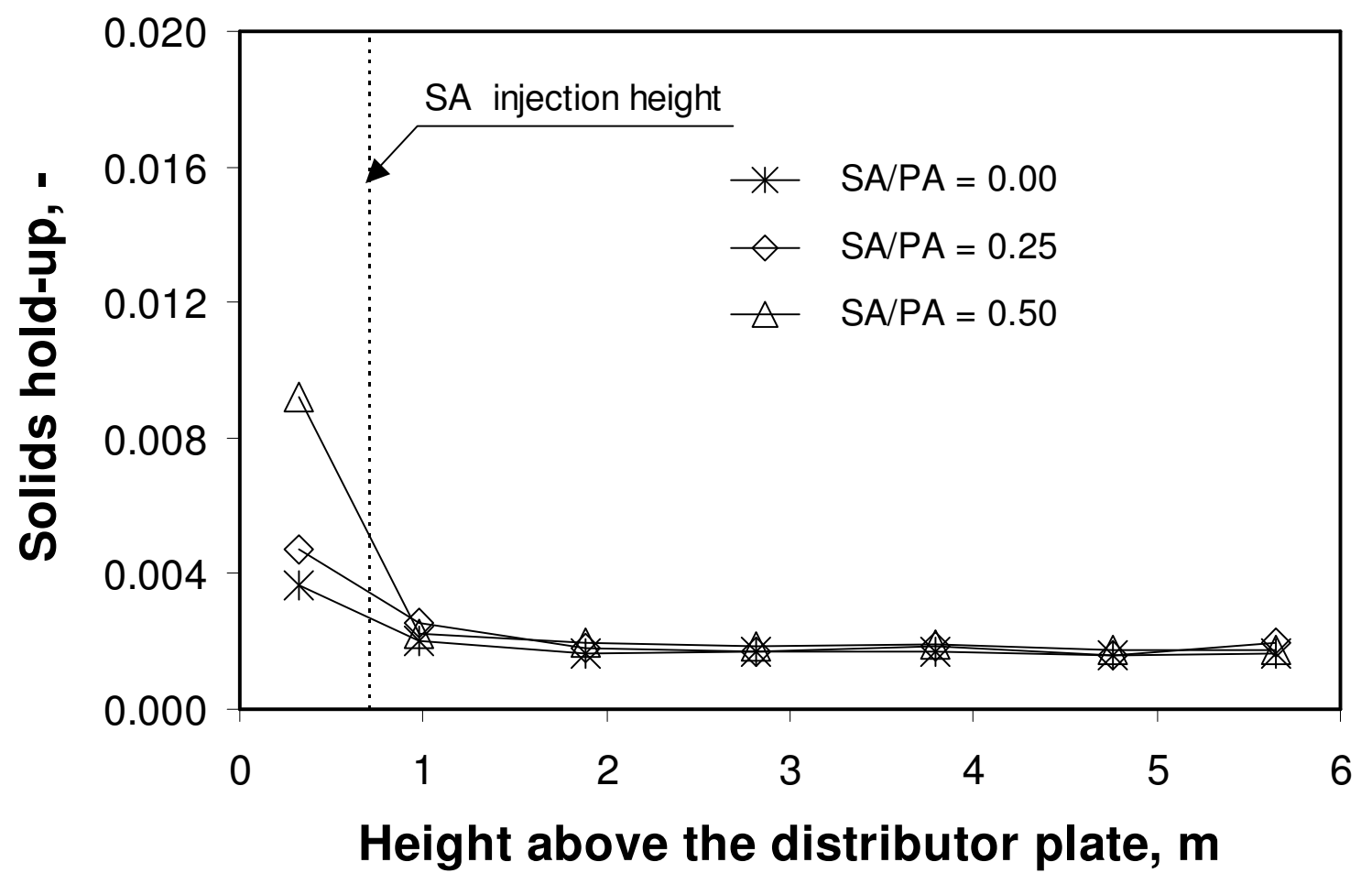

Figure 3.

Koksal et al. 


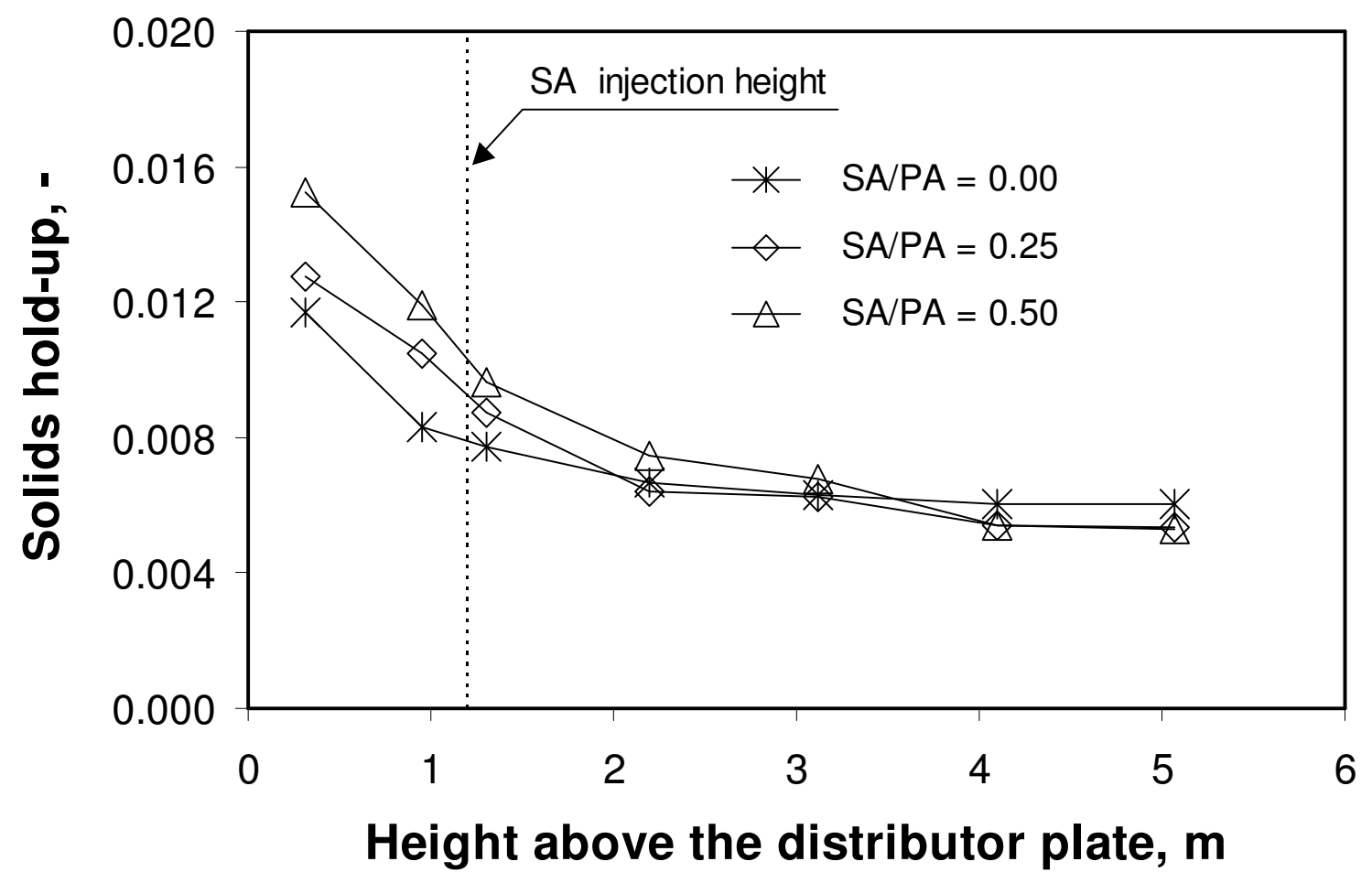

Figure 4.

Koksal et al. 


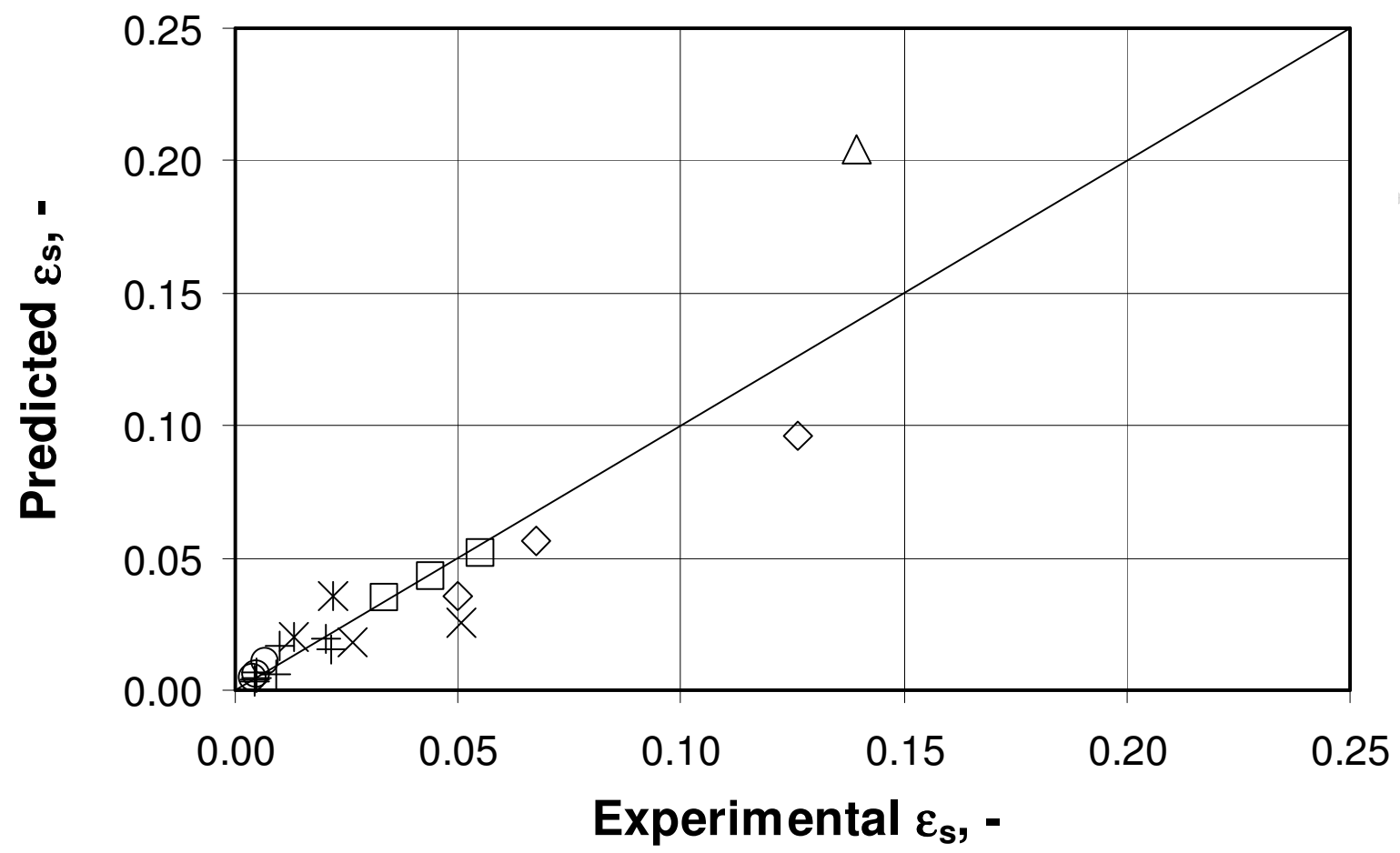

Figure 5a.

Koksal et al. 


\section{ACCEPTED MANUSCRIPT}

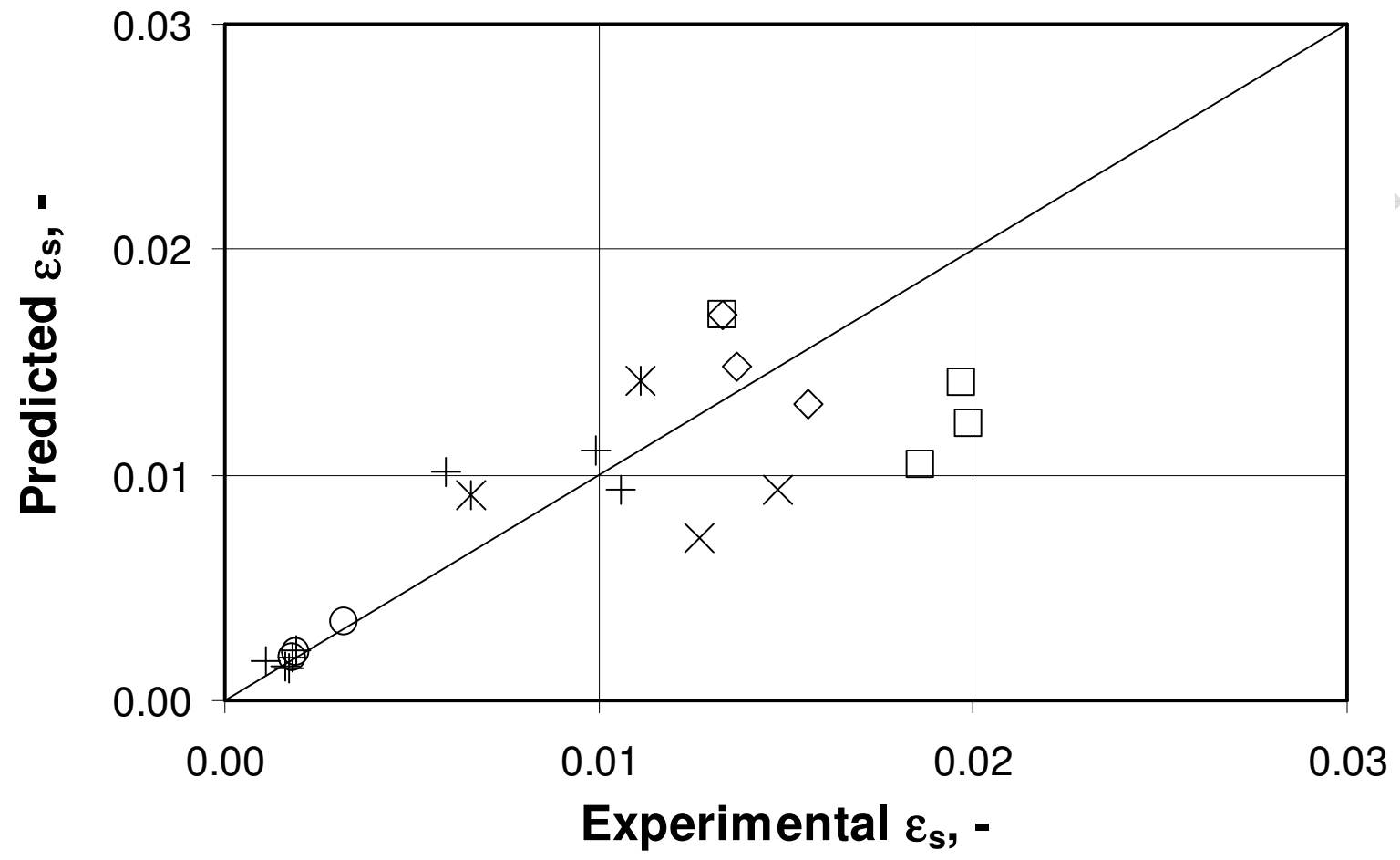

Figure 5b.

Koksal et al. 


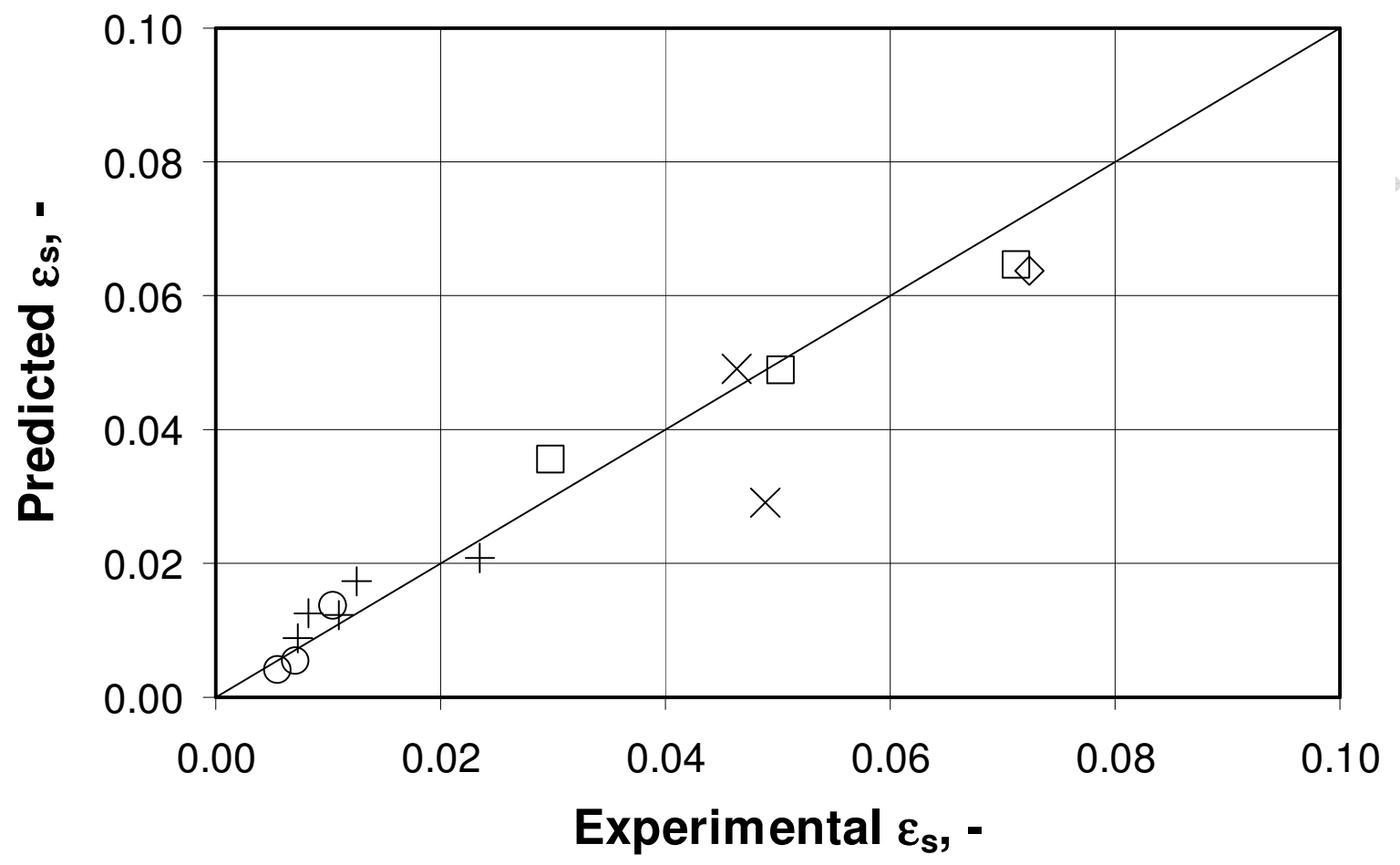

Figure 6a.

Koksal et al. 


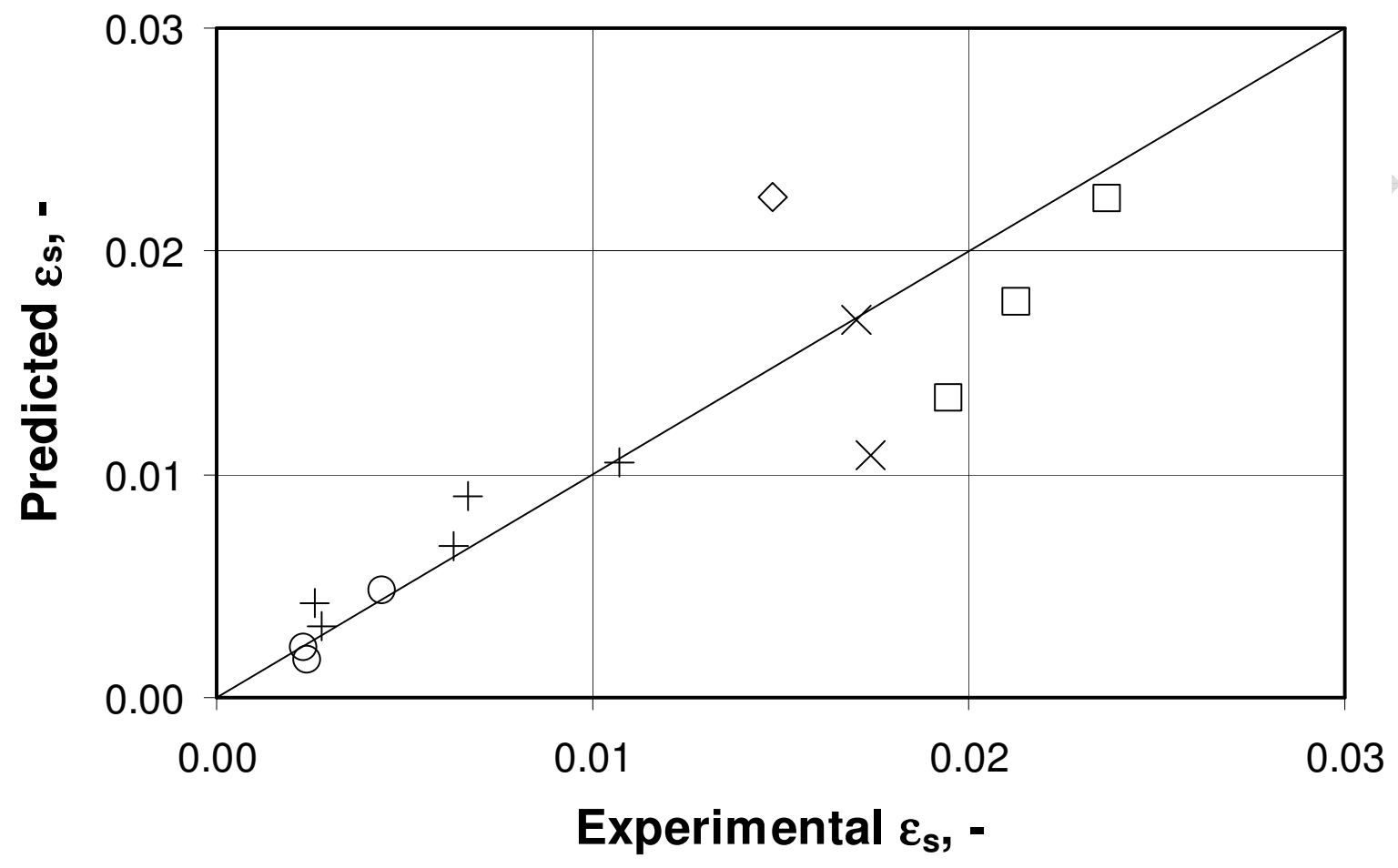

Figure 6b.

Koksal et al. 


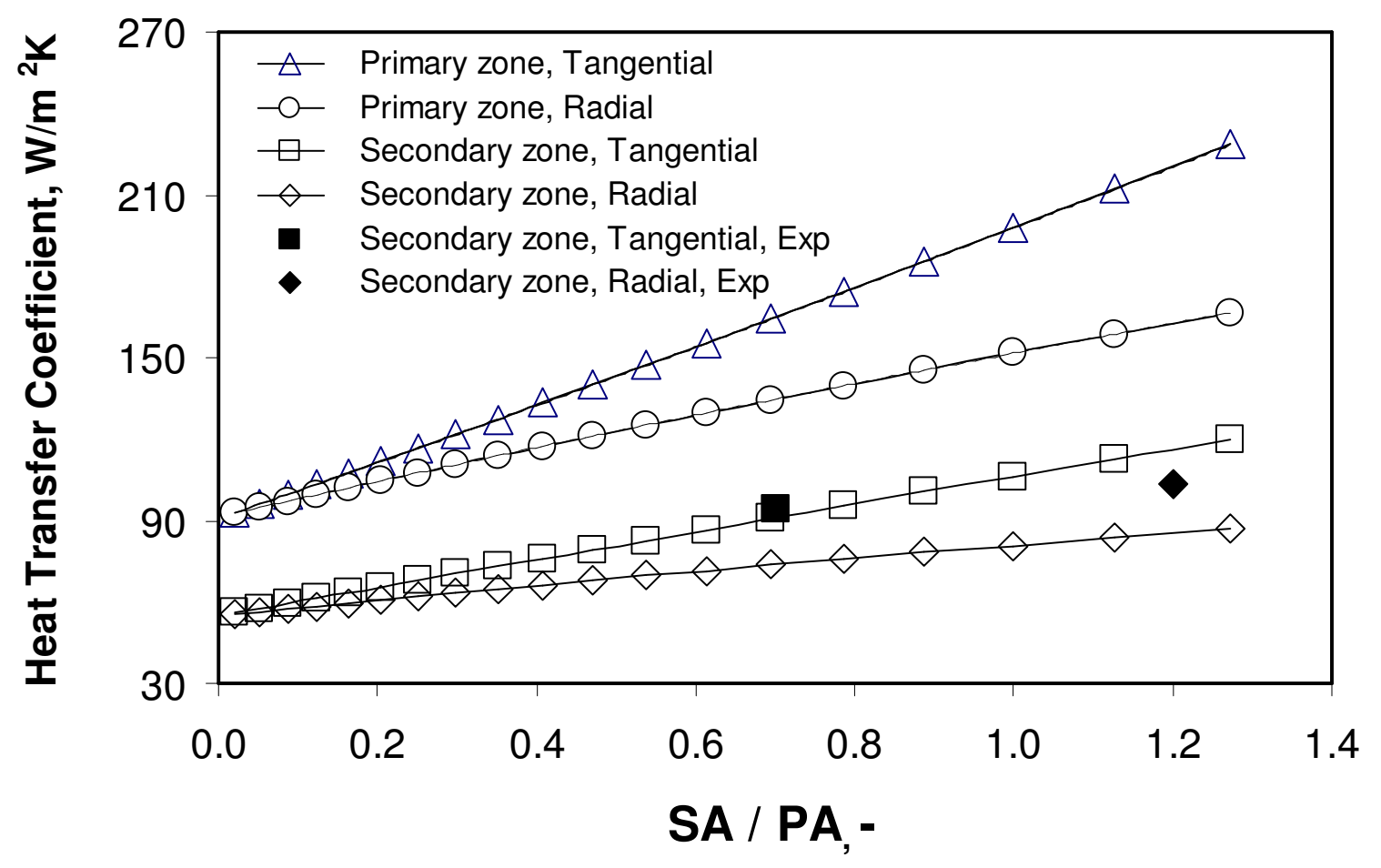

Figure 7.

Koksal et al. 


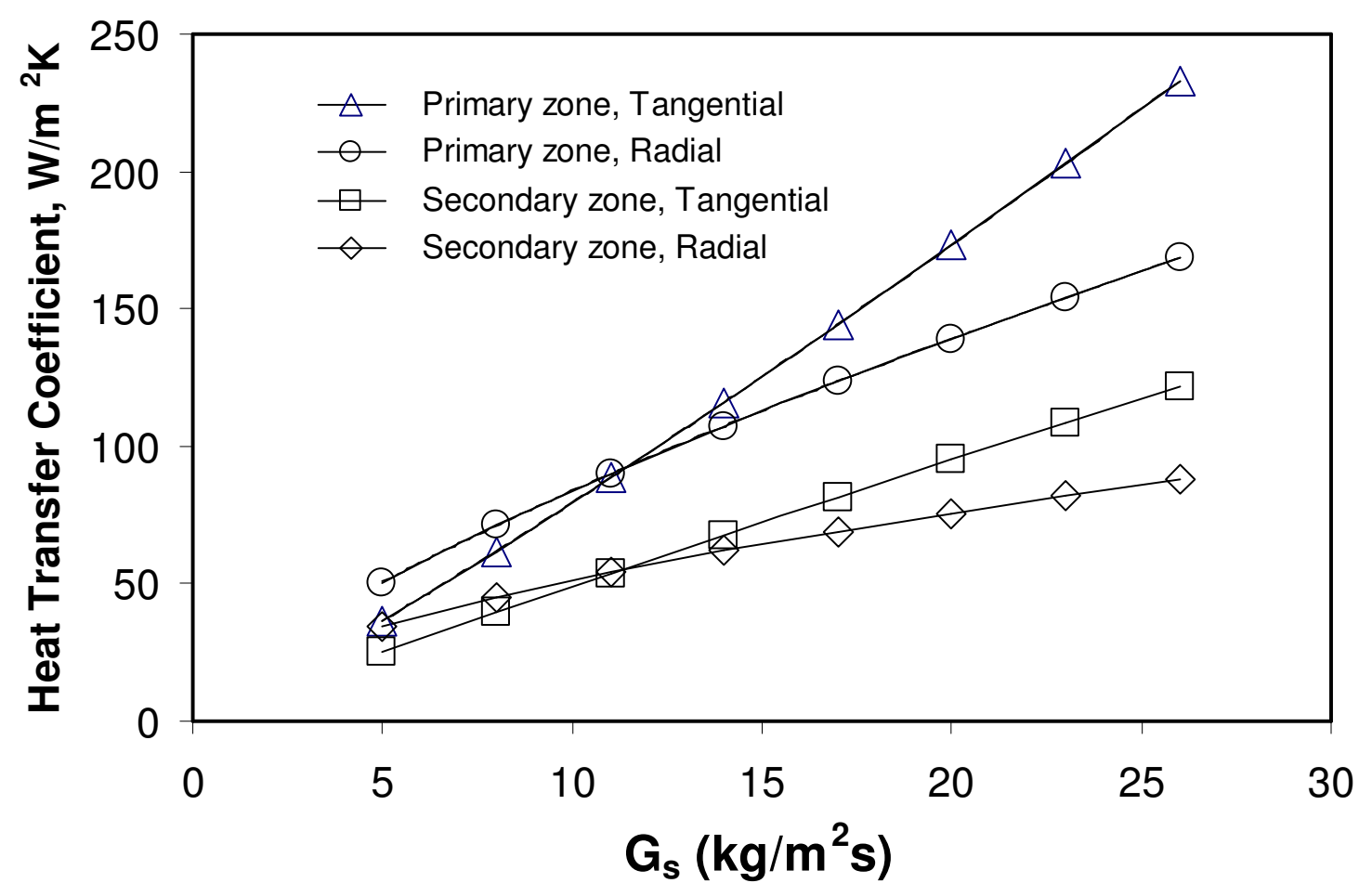

Figure 8.

Koksal et al. 


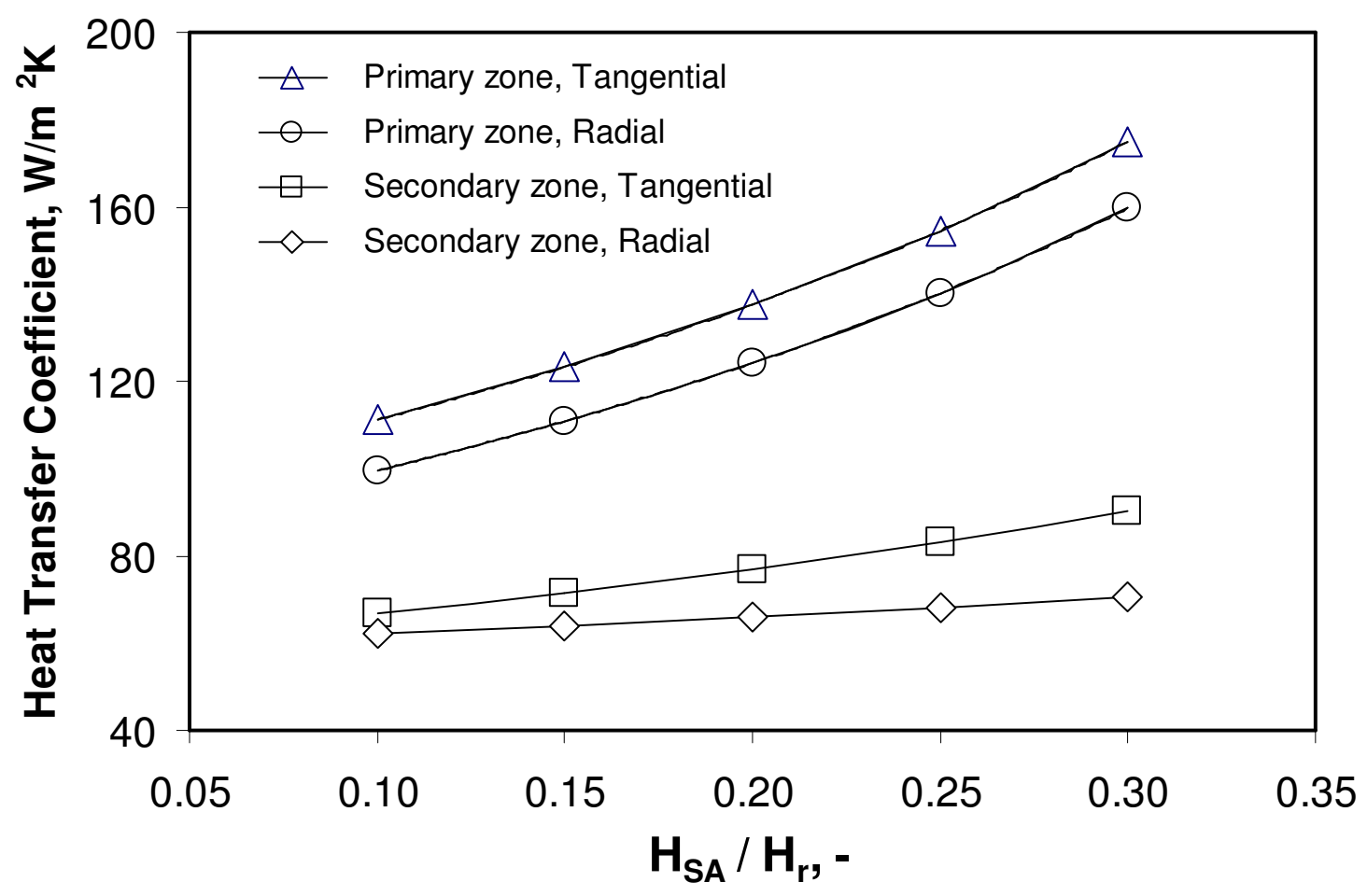

Figure 9.

Koksal et al. 


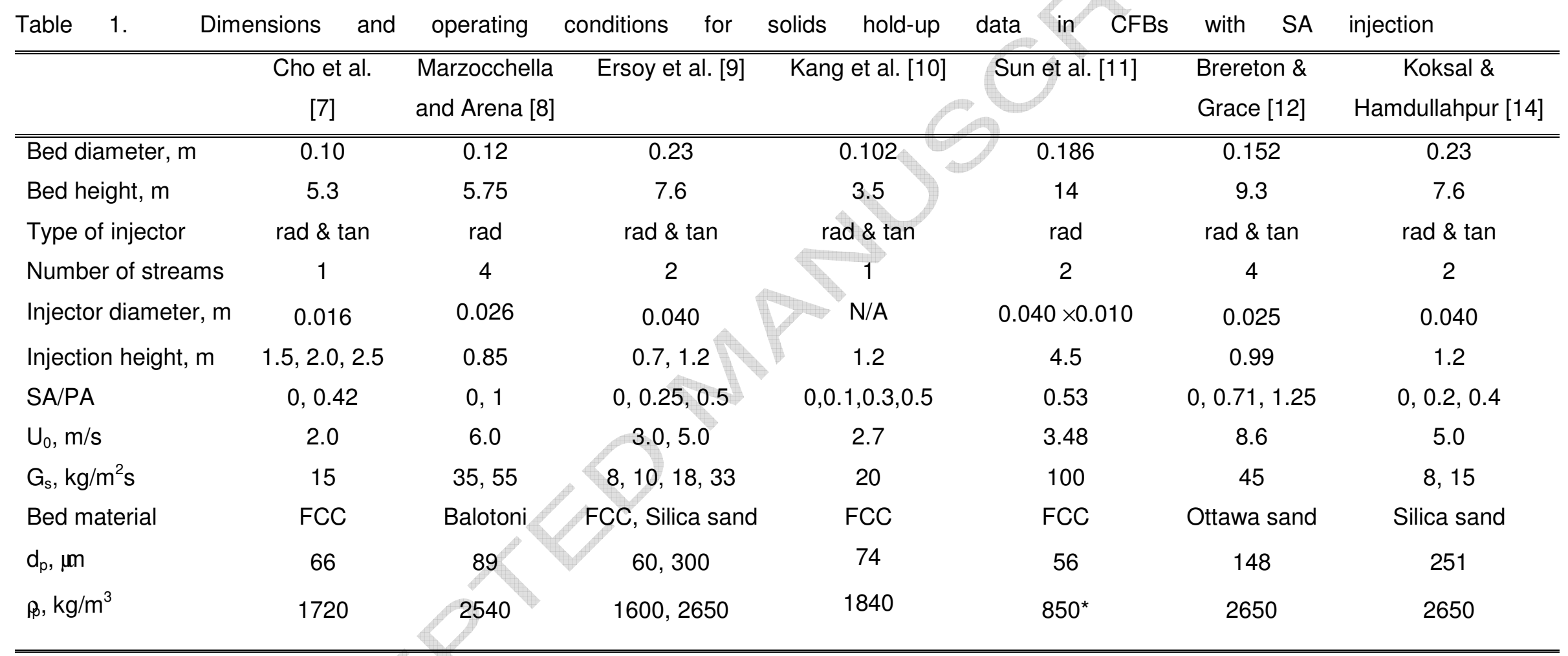


Table 2. Parameter values used for the simulations.

\begin{tabular}{lc}
\hline \hline Parameter & Value \\
\hline \hline Gas density, $\rho_{s}$ & $1.2 \mathrm{~kg} / \mathrm{m}^{3}$ \\
Particle density, $\beta$ & $2600 \mathrm{~kg} / \mathrm{m}^{3}$ \\
Particle diameter, $d_{p}$ & $200 \mu \mathrm{m}$ \\
Superficial gas velocity, $U_{0}$ & $5 \mathrm{~m} / \mathrm{s}$ \\
Secondary air gas velocity, $U_{S A}$ & $1.25 \mathrm{~m} / \mathrm{s}$ \\
Solids circulation rate, $G_{s}$ & $15 \mathrm{~kg} / \mathrm{m}^{2} \mathrm{~s}$ \\
Riser length, $H_{r}$ & $7.6 \mathrm{~m}$ \\
Riser diameter, $D_{r}$ & $0.23 \mathrm{~m}$ \\
Height of secondary air port, $H_{S A}$ & $1.2 \mathrm{~m}$ \\
\hline \hline
\end{tabular}

